\title{
ТАҒДЫРЫ ЖҰМБАҚ ҚЫШҚАЛА
}

\author{
(С) 2018 ж. Д.А. Талеев, М. Елеуов, С. Есенов
}

Мақалада Қызылорда қаласынан оңтүстікке қарай 30 км жерде, Қоғалыкөл ауылының маңында орналасқан Қышқала қалашығында 2018 ж. жүргізілген археологиялыққазбажұмыстарынәтижесіжайлымәліметтербаяндалады.Қышқаланың осыған дейінгі археологиялық зерттелу тарихына шолу жасалып, оның деректерден белгілі тарихи қаламен баламалану мәселесі қарастырылған. Қалашықтың тарихи атын анықтауда мамандар арасындағы әртүрлі көзқарастар сараланған. Сондай-ақ көпшілік мамандардың Қышқаланың Сырдарияның көне арнасы Баршындарияның бойындағы Баршынкент қаласының орны деген пікірлеріне сүйене отырып, Баршынкент қаласы туралы сақталған жазба деректердің мәліметтері топтастырылған.

Түйін сөздер: археология, Қызылорда, Көлтоған, Қышқала, Қыштөбе, зерттеу, деректер, баламалау, қазба, барлау, топография

Кезінде ортағасырлық қаланың орны болған Қыштөбе қалашығы Қызылорда қаласынан оңтүстікбатысқа қарай 25 км жердегі Қоғалыкөл ауылының оңтүстігінде 2 км жерде, Сырдарияның сағасы Жаңадарияның оң жағалауында жатыр. Сыртында қорғаныс қабырғалары жоқ, мәдени қабаты 1-2 метрге дейін сақталған қалашық 50 гектарға жуық аймақты алып жатыр (сур. 1). 30 гектар шамасында болатын орталық бөлігі біртұтас және үстінде күйдірілген қыш сынықтары өте көп. Сондықтан болар жергілікті тұрғындар бұл қалашықты Қыштөбе (Қышқала) деп атап кеткен. Ал шеткі аймақтары жеке-жеке жатқан төбешіктерден тұрады. Олар негізінен қалашықтың шығыс және оңтүстік бөлігін алып жатыр. Бұлар шамасы бір кездегі жеке иеліктердің (усадьба) орындары болуы мүмкін.
Қалашықтың географиялық координаттары: С.4444'27"; Ш.65²11'03", теңіз деңгейінен биіктігі 122 м. Ескерткіштің басым бөлігін бұл күнде шеңге, жыңғыл және сексеуіл басып кеткен.

Қалашықтың зерттелу тарихы шым-шытырық. Олай дейтініміз Қыштөбе зерттеушілерге XIX ғасырдың екінші жартысынан бастап белгілі болғанменен XXI ғ. ғылымында ескерусіз қалған. 2011 ж. жарық көрген Қазақстан Республикасының тарихи және мәдени ескерткіштерінің жинағының Қызылорда облысына арналған 504 беттік жинағына енбей қалған. Тіпті облыстық ескерткіштерді қорғау инспексиясының ресіми тізімінде алынбай келген. Алғаш қалашық жайлы мәлімет Түркістандық археологиямен қызығушылар үйірмесінің белді мүшесі В. Каллаурдың 


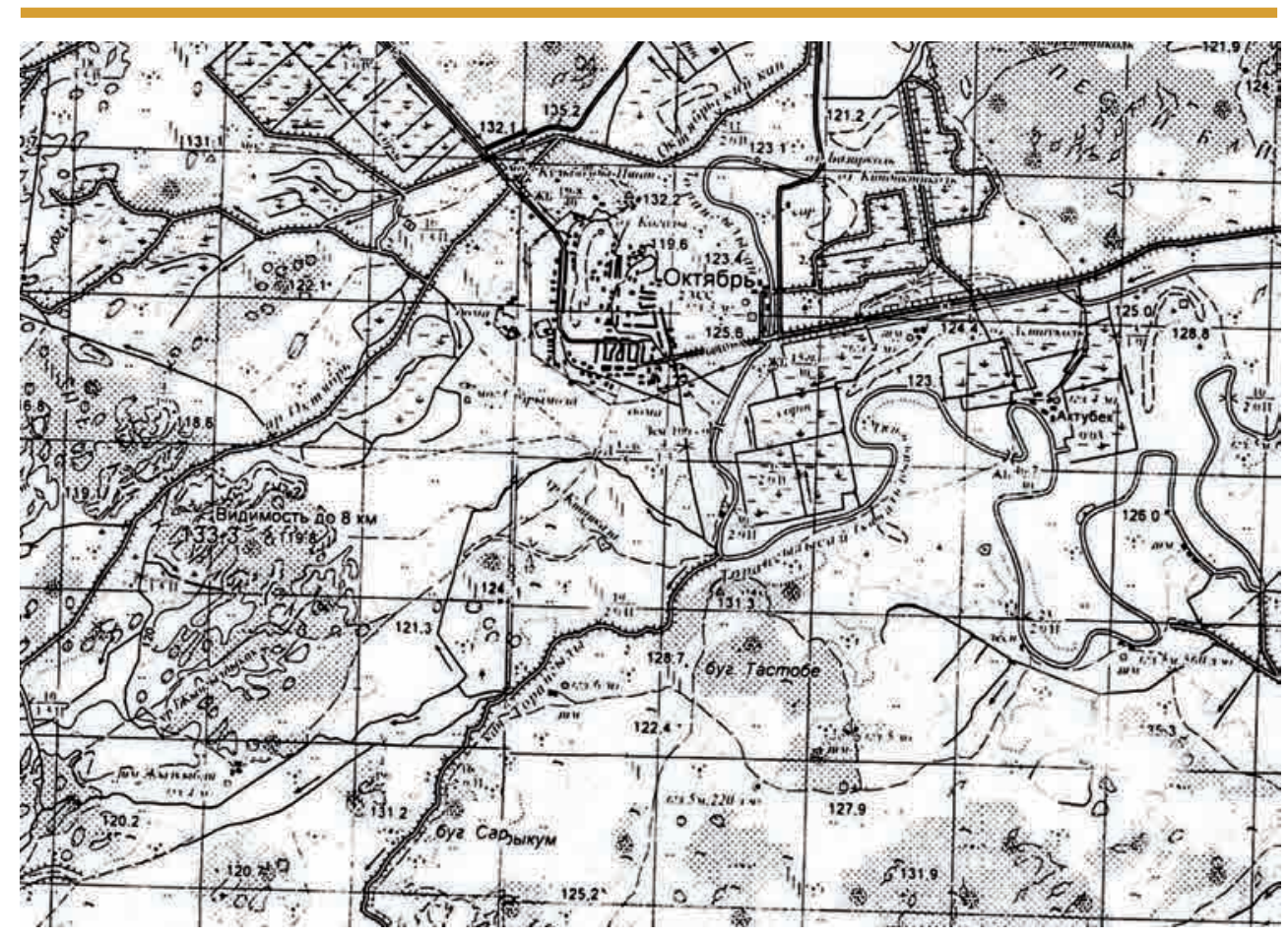

Сур. 1. Қышқ̧ала қ̧алашывы орналасқ̧ан аймақтың картасы

Fig. 1. Map of the settlement of Kyshkala

мақаласында айтылады [Каллаур, 2011a, с. 245; 2011б, с. 211]. Ол өзінің Перовск уезіндегі 1219 ж. Шыңғысхан талқандаған қалалар жайлы мақаласында Перовскіден 2530 км жерде Кыс-Кала (Гыш-Кала) жатқаны жайлы айта келіп, оны Жент қаласының орны болуы мүмкін деген болжам жасаған.

1946 жылы

С.П. Толстов басқарған Хорезм археологиялықэтнографиялық экспедициясы (ХАЭЭ) қышқалада [С.П. Толстов бойынша Кыш-төбе - авт. ескертпесі] болып, оның үстінде шашылып жатқан ыдыс сынықтарын, заттарды жинап, картада Қыштөбенің ортағасырлық Асанас пен Женттің аралығында орналасқанын көрсеткен [Толстов, 1948]. Қыштөбені Ә.Х. Марғұлан өзінің ортағасырлық қалалар жайлы монографиясында Сырдарияның төменгі ағысында болған Барчинкент (Барчинлыкент) Жент пен Жанкенттің аралығында орналасқан деп берген. Сондайақ ол қаланың орны Қызылорда мен Шиелінің аралығындағы Қызқала деп көрсеткен [Марғұлан, 1950, . 76-78]. Қалашықтың орналасқан жері К.А. Ақышыптың жетекшілігімен 1960 жылы жарық көрген Қазақстанның археологиялық картасында Қызылорда қаласынан оңтүстік-батысқа қарай 25 км жердегі жекелеген құрылыстар қирандысы Қызқала деп берілген [Археологическая карта Казахстана, 1960, с. 225, № 3318].

1960 жылы белгілі әдебиетші Ә. Қоңыратбаев Ғ. Мұсабаевпен бірге Қышқалада бақылау жұмыстарын жүргізген. Ол туралы Ә. Қоңыратбаев өз еңбегінде былай деп жазған: «Қышқала демектің мағынасы онда қыштан салынған кішігірім Сарай 
(орда) болған.... 1960 жылы біздер бірер метр жерін қазып, күйдірілген кірпіштен жасалған бармақтай сырлы құмыра таптық. Ішіне 25 грамм су кетеді, тұтқасы сынған. Осы төбенің астынан күміс ақша табылған. Сол жерден 1960 жылы мен сор бетіне шығып қалған алтын теңге таптым» [Қоңыратбаев, 1987, 336 б.; 2004, 151 б.]. Сонымен қатар Ә. Қоңыратбаев Қышқаладағы моладан адамның, аттың сүйектері, сырланған көзелер сынығы табылғанын айта келіп: «Бірақ бұл жерде [Қышқаланы айтып отыр авт. ескертпесі] қамалдың ізі жоқ... «Қышқала» деген атау ел аузында жүрген кейінгі сөздер болса керек. Сыр бойында ондай қаланың аты жоқ» - дейді [Қоңыратбаев, 1987, 336 б.]. Қыштөбенің маңындағы Қоғалыкөл ауылының тұрғыны Исламбек ақсақалдың айтуынша Қыштөбеге 1976 жылы Ә.Х. Марғұлан Ә. Қоңыратбаевпен бірге қайта келген. Сол сапарында ішінде мыс теңгелері бар кішігірім құмыра табылған. Құмыраны Ә.Х. Марғұлан өзімен бірге алып кеткен. Бірақ, сол сапары жайлы академик ешқандай жазба мәлімет қалтырмаған. Шамасы Ол кісінің қолжазбасы жарияланбай қалса керек.

Қышқала қалашығында алғашқы археологиялық қазба жұмыстарына 1990 ж. Қызылорда мемлекеттік пединститутың Т. Мәмиев басқарған студенттер тобы мен әл-Фараби атындағы Қазақ Ұлттық университетінен арнайы шақырылған М. Елеуов пен Д.А. Талеев келіп қатысты [Мәмиев, 1999, 27 б.]. 1990жылдарда Қышқалада жүргізілген қазба жұмыстарының барысы, онан ашылған құрлыстар, табылған археологиялық заттар Т. Мәмиевтің «Кейінгі ортағасырдағы Арал өңірінің қалалары (XIII-XVIII ғғ.)» тақырыбына тарих ғылымдарының кандидаты ғылыми дәрежесін алу үшін жазған диссертациялық жұмысында қысқаша жазылған [Мәмиев, 2000, 64-69 б.].

$$
\text { Мәмиев Қоғалыкөл ауы- }
$$
лынан 2 км оңтүстік-шығыста орналасқан Қышқалада зерттеу жұмыстарын жүргізген кезде оның діни, қоғамдық, азаматтық құрылыстар қирандыларының орны дөңгелек төбелерден тұратынына көңіл аударған. Мысалы, Мәмиев өз есебінде бірінші төбенің диаметірі 200 м, биіктігі 2 м, екінші төбенің диаметірі 300 м, биіктігі 2,5 м ал үшінші төбенің диаметірі $300 \mathrm{M}$, биіктігі 3 м, төртінші төбенің диаметірі 500 м биіктігі 5 м деп көрсеткен. Олардан табылған қыш кірпіштердің өлшемдері $25 \times 7 \times 12 \mathrm{~cm}, 25 \times 6 \times 27 \mathrm{~cm}$. Ол 1992 ж. солтүстіктен оңтүстікке қарай өткен орталық көшесіндегі мешіт және тұрғын үй кешендерінде археологиялық қазба жұмыстарын жүргізді [Мәмиев, 2000, 52 б.]. Қазба барысында табылған жапсырма өрнегі бар плиталардың сынықтары табылды. Онда араб тілінде жазылып көгілдір, ақшыл түспен өрнектер салынған. Қазба барысында көптеген сырлы және сырланбаған ыдыс сынықтары мен шыныдан жасалған ыдыс сынықтары, моншақ үзінділері кездесті.

Сол кезде салынған стратиграфиялық қазба нәтижесі бойынша құрылыс қабаты 60 см тереңдіктен тұрады. Оның жоғарғы 10 см тығыз қабаттан, 7 см ағаш пен қамыс күлі аралас қабаттан, 20 см қамыс, 3,5 см кесек аралас бос қабаттан түзілген. Қазба барысында аршылған үй құрылыстарының топографиясы мен табылған заттар кешенін Отырар қаласының мате- 
риалдарымен салыстыра келе автор қалашық XIII-XVIII ғғ. аралығында өмір сүрген деген болжам жасаған. Қазбадан табылған мыс бақырларды Ә.Х. Марғұлан атындағы Археология инситутының мамандары Р.3. Бурнашева мен С. Юсупова зерханалық сараптаудан өткізген [Мәмиев, 2000, 64-68 б.]. Мәмиевтің есебінде қалашықтың қолдан сызылған жобасы, қазбаның жобасы және қазбадан табылған жәдігерлердің суреттері берілген.

Жергілікті тұрғындардың мәлімдеуінше содан кейін де археолог мамандар Қыштөбеде бірнеше рет болған, кішігірім қазба да салынған бірақ, ол туралы ешқандай есеп жоқ. Ең өкініштісі Қызылорда облысының тарихи-мәдени ескерткіштерінің жинағына Қыштөбенің енбей қалғаны. Ескерткіш 1960 ж. жарық көрген Қазақстанның археологиялық картасында бола тұрып, осы күнгі мамандардың назарынан тыс қалған. Жоғарыда берілген қалашықтың сипаттамасы 2018 ж. құрылған Қышқала археологиялық экспедициясының (М. Елеуов) зерттеулері нәтижесі.

Жазба деректері мен баламалану мәселесі

Жазба деректері туралы айту үшін алдымен қалашықтың тарихи атын анықтау, яғни баламалану мәселесіне тоқталу қажет. Көпшілік зерттеушілер Қыштөбені немесе Қышқаланы (Қызқала) ортағасырлық бірсыпыра деректерде кездесетін Баршынкет қаласының орны деп болжаған және оған қарсы пікірлер де болған. Енді соларға қысқаша тоқтала кетелік. В.А. Каллаур 1899 ж. өзі ашқан Қышқаланы Қысқала (Гышкала) деп атап, оны Жент қаласымен баламалаған [Каллаур, 2011б, с. 211], сонымен қатар, ол Жөлектен 80 верст жерде орналасқан Барчинлыг- кент (Бархалыгкент) қаласы бар деп көрсеткен [Каллаур, 2011a, с. 286].

Қышқаланы Баршынкенттің орны болуы мүмкін деген пікірді алғаш айтқан Ә.Х. Марғұлан болатын. Ол қаланың атауын Алпамыс батыр жырындағы Гүлбаршынның есімімен байланыстырған [Маргулан, 1950, с. 76-78]. Каллаур Сырдарияның Өзкенттен Сырлытамға дейінгі және одан әрі қарайғы көне арналарнасы Баршындария деп аталған расталса, онда Барчынлыгкен сол дарияның бойында болуы тиіс [Каллаур, 2011а, с. 211; 2011б, c. 245]. Ондай жағдайда жоғарыда сипатталған Төбесіойық (Қасым ата) қалашығы Барчынлыгкентің қираған орны болуы мүмкін ғой? деген ой салған. Сондай-ақ В.А. Каллаур Өзгент, Бархалыгкент, Ашнас және Жент қалаларының орналасу ретіне тоқтала келіп: «... Джучи - хан после разрушения Саганака отправился в Узгент, затем в Бархалыгкент, Ашнас и Джент: следовательно, Бархалыгкент должен быть ниже Узгента и по пути в Ашнас» - деген де пікір қалдырған [Каллаур, 2011a, с. 245]. В.А. Каллаурдың бұл пікірімен келісу қыйсынсыз, себебі П. Карпинидің жазғаны бойынша Ианкинт, Бархин және Орнас (Асанас) қалалары осы ретпен орналасқан [Путешествие..., 1993, c. 41].

В.В. Бартольд Қышқаланы Жентпен баламалаған В.А. Каллаурдың пікіріне қосыла отырып [Бартольд, 1965, с. 235], Өзгенттен 7 верст жердегі Каллаур сипаттаған, аумеғы 600 қадам келетін шағын бекіністің құландысын [Төбесіойық - авт. ескертпесі] Барчынлыгендтің орны болса керек дейді [Бартольд, 1965, с. 228]. Ал Императорлық археологиялық коммисияның мүшесі, археолог П. Лерхтің «Ар- 
хеологическая поездка в Туркестанский край в 1867 году» атты еңбегінде Бархалигкенд деген қала Сығанақ пен Өзгент қалаларының аралығында деп көрсетілген [Лерх, 1870, с. VII]. Енді Қышқала мен Баршынкенттің баламалануыжөнінде Ә. Қоңырытбаевтың болжамдарына тоқталсақ: «В.А. Каллаурдың айтуынша Жент қаласының орны-Қышқала (Томарөткел).... Жентікөлдің батысында Баршынғылкент, Рабат Туғани қаласы болған». «... Қышқала демектің мағынасы - онда қыштан салынған кішігірім сарай (орда) болған. Сонда қыш көп табылған. Бұл сарайдың орны бар» [Қоңыратбаев, 2004, 336 б.; 1987, 151 б.].

1960 жылы Қышқалада зерттеу жүргізген Ә. Қоңыратбаев Жент пен Баршынкенттің баламалануына тоқтала келіп, олар туралы былайша болжам жасаған: «Сонымен біз Жент екеу болған дейміз. Бірі Қуандарияның сағасындағы ескі хұнн Женті, екіншісі X ғасырдағы Сейілхандар салған Жент. В.А. Каллаур айтқан Жент - соңғысы болуы тиіс (Томарөткел). Сол сияқты Баршынкенттің орны кесене емес, Қызылқұмда тұрған, Баршындария жағасына салынған Сырлытам болуға тиіс» [Қоңыратбаев, 1987, 344 б.; 2004, 158 б.].

C. Жолдасбайұлы Баршынкент туралы Ә. Қоңыратбаевтың жүргізген зерттеулеріне сүйене оырып: «... сонымен осы Баршындария сағасындағы Сырлытам мазары мен оның жанындағы елді мекенді Баршынкент деген қортындыға келген. Қортындылай келгенде, Баршынкент атының біз жоғарыда келтірген XIII ғ. орта кезіндегі жазба деректерде кездесуі, ертедегі аңыздар мен батырлар жырындағы хабарлар мен сәйкес келуі бұл аймақтағы соңғы кездегі ел аузындағы кенттің, атының сақталуы, дарияның Баршын аталуы жай нәрсе еместігін байқатады. Олай болғанда оғыздармен қыпшақтар өмір сүрген Баршынкет мекенінің болғандығы сөсіз» деп жазған [Жолдасбаев, 1996, 101 б.].

Қышқаланы тікелей Баршынкент қаласымен баламалаған зерттеушілердің бірі Қорқыт Ата Мемлекеттік университетінің бұрынғы оқытушысы Тәңірберген Мәмиев XX ғ. 90-жылдары онда археологиялық қазба жұмыстарын жүргізген [Мәмиев, 1999, 16 б.; 2000, 27 б.]. К.М. Байпақов Ортағасырлық Қызтөбені Барлыгенд (Баршынкент) деп атап, картада оны Қызылордадан батыста, дарияның оң жағасына орналастырған [Байпаков, 2007, c. 38].

Егер осы пікірлер едәуір нанымды болжам деп қабылдар болсақ, онда Баршынкент туралы мәліметтер жазба деректер XIII ғ. ортасынан басталады. 1245-1247 жылдары аралығында Рим папасының монғолдың ұлы ханы Мөңкеге жіберген елшісі Плано-Карпинидің жолжазбалары әзірге алғашқы болып отыр [Путешествие..., 1993, с. 41]. Жолжазбада Бархим деп берілген қала Шыңғыс хан әскерлеріне ұзақ уақыт берілмегені туралы айтылады. Одан кейін 1253 ж. монғолдың ұлы ханы Мөңкеге елшілікке аттанған армян патшасы Гетумның жолжазбасында Сгнах (Сығанақ), Савран (Сауран), Харчук (Қарашық), Хузақ (Созақ), Асон (Асанас) қалаларымен қатар Парчын (Баршын) қаласының аты да аталады [Извлечения из книги..., 2005, с. 41]. Осы сапар жайлы жазылған К. Ганзакецидің «История армян» атты кітабындағы Парчын 
қаласының Барджент (Баршын) болуы мүмкіндігін П.И. Лерх та растайды [Лерх, 1870, с. 11].

Одан кейін XIV ғ. басында жазылған Жамал Қашқаридің «Әлмұхаммед-ас-Сұрақ» («Лұғатқа қосымша») атты еңбегінде кездеседі. Ол Баршынкентте садырлардың садыры, әл-әлам, шейх әл-ислам Хусам әл-илла ва-д-дин Абу-л-Махамед Хамид и ибн Асим әл-Асим әлБаршылықтан дәріс алғаны турала жазады [История Казахстана..., 2005, c. 155-156]. Шыңғысхан қайтыс болғаннан кейін Баршынкенттің Жент, Хорезім қалаларымен бірге Бату ханның иелігінде болғандығы жайлы осы Жамал Қаршидің кітабында айтылады [История Казахстана в персидских источниках, 2005, с. 120].

Баршынкент қаласы туралы аса құнды деректер Ә. Дербісалиевтің «Қазақ даласының жұлдыздары» атты тарихи-филологиялық зерттеуінде кездеседі. Ғалым бұл еңбегінде Баршынкент қаласында туып-өскен ортағасырлық ғұлама-ғалымдар туралы және Баршынкент қаласына келіп, Сырдарияның төменгі ағысындағы басқада ортағасырлық қалаларда туып өскен ғұламалармен кездескен жат жеріліктердің еңбектеріне жан-жақты тоқталып шолу жасаған [Дербісалиев, 1995, 110 б.]. 1273-1274 жылдары Сыр бойындағы қалалар мен онда тұратын халықтардың тарихын хатқа түсіру ниетімен арнайы келген Жамал Карши болды. Жамал өз дүниесін әуелі Баршынкент жайлы мағлұматтар беруден басталған. Оны ол қала емес мекен (дияр) деп атаған. Соған қарағанда сол кезде Баршынкент шынында да бекіністік дәрежедегі қыстақ қана болған сияқты [Дербісалиев, 1995, 110 б.]. Дияр (мекен) немесе қыстақ қана болғанымен Баршынкент белгілі мәдениет орталығы болған. Мұнда дуалы ауыз шешендер мен жезтаңдай әншілер, сөз өнерінің белгілі майталмандары ғұмыр кешкен [Дербісалиев, 1995, 111 б.].

Сонымен, деректерде, зерттеушілердің еңбектерінде Бархин (П. Карпини), Парчин (Гетум), Барчканд (Жамал Карши), Барчинлигкент, Барчканд, Барчкенд (Ә. Дербісалиев), Барчин (Жошы теңгелерінде), Баэр-чи-ли-Хань, Ба-эрчжень (қытай транскрипциясы бойынша), Барчынлыгенд (Барчкенд), Барчынлыген, Хышт-қала, Баршын, Баргент (В.В. Бартольд), Барлычгенд (К.M. Байпақов), Барчынлыгент (В.М. Жирмунский), Бархалигкенд (П. Лерх), Барчынлыгент, Бархалыгкент, Барчинлыкент (В.А. Каллаур), Баргенд, Барчынлыгенд (А.И. Маленин), Баршынкент (Ә. Марғұлан, Ә. Қоңыратбаев, С. Жолдасбайұлы, T. Мәмиев) аталған қалалардың барлығы бір қаланың әртүрлі аталуы (аты). Ал зерттеушілердің еңбектерінде Кыс-Қала, Гыш-Қала (В.А. Каллаур), Хыш-кала (В.В. Бартольд), Қыз кала (Археологическая карта Казахстана), Қыш төбе (С.П. Толстов), Қызтөбе (К.М. Байпаков), Қышқала (Ә. Қоңыратбаев), Баршынкент (Т. Мамиев) деп түрліше аталып келген қаланың орны қазіргі Қышқалаға сәйкес келеді.

Біз қазіргі Қышқаланың орнын ортағасырлық Баршынкент қаласымен баламалаған Ә.Х. Марғұланның пікіріне қосыла отырып, өз тарапымыздан айтарымыз: біріншіден, П. Карпини Бархин қаласы Жанкент пен Асанас қалаларының аралығында орналасқан деп дұрыс көрсеткен; екіншіден, бұл қаланың орналасқан жері, тарихи құрылымы Ж. Карши болған мекен Барчкандқа сай келеді. Барчканд пен Баршынкент екеуі бір қаланың аты. 
Талеев Д.А., Елеуов М., Есенов С. Тағдыры жұмбақ Қышқала

Қышқалада 2018 жыль жүргізілген құазба жұмыстары

Зерттеудің негізгі мақсаты ортағасырлық Қышқала қалашығында археологиялық қазба жұмыстарын жүргізіп, оның материалдық және рухани мәдениетін, шаруашылық дәстүрін, Әлеуметтік - экономикалық ахуалының негізгі элементтерін археологиялық мәліметтер мен материалр негізінде зерделеу болып таблады.

Қазба қалашықтың екі жерінен салынды. Қазба I ескерткіштің солтүстік-батыс шетін алып жатқан қала бейіті аумағында орналасқан екі биік төбешіктің біріне салынды. Үстінгі жағында күйдірілген кірпіштер мен бір беті сырланған, бетіне өрнек салынған кірпіш сынықтары шашылып жатқан төбешіктің көлемі $30 \times 32$ м. Кейін анықталғандай кезінде едіуір келбетті кесененің орны болған төбенің солтүстік-батыс шетінен біз салған (2018 ж.) қазбаның жалпы көлемі $12 \times 12$ м (сур. 2). Қазылған тереңдігі $0,25 \times 0,8$ м. Жүргізілген қазба барысында қас беті солтүстікке қараған бір кездегі тамаша кесененің қираған орнының бір бөлігі ашылды. Кесененің алдыңғы жағына төселген тікбұрышты кірпіш төсендісінің үстіне құлаған ғимараттың қас бетінің құландысы сол құлаған күйінде бетімен төмен қарап жатыр екен. Аркалы есігінің үстіңгі жағы мен оның шеттерін безендірген төртбұрышты кесіп салынған өрнекті қыш сылақтар мен оның айналасындағы майолика мозайкалары беттерімен төмен қарай жатыр.

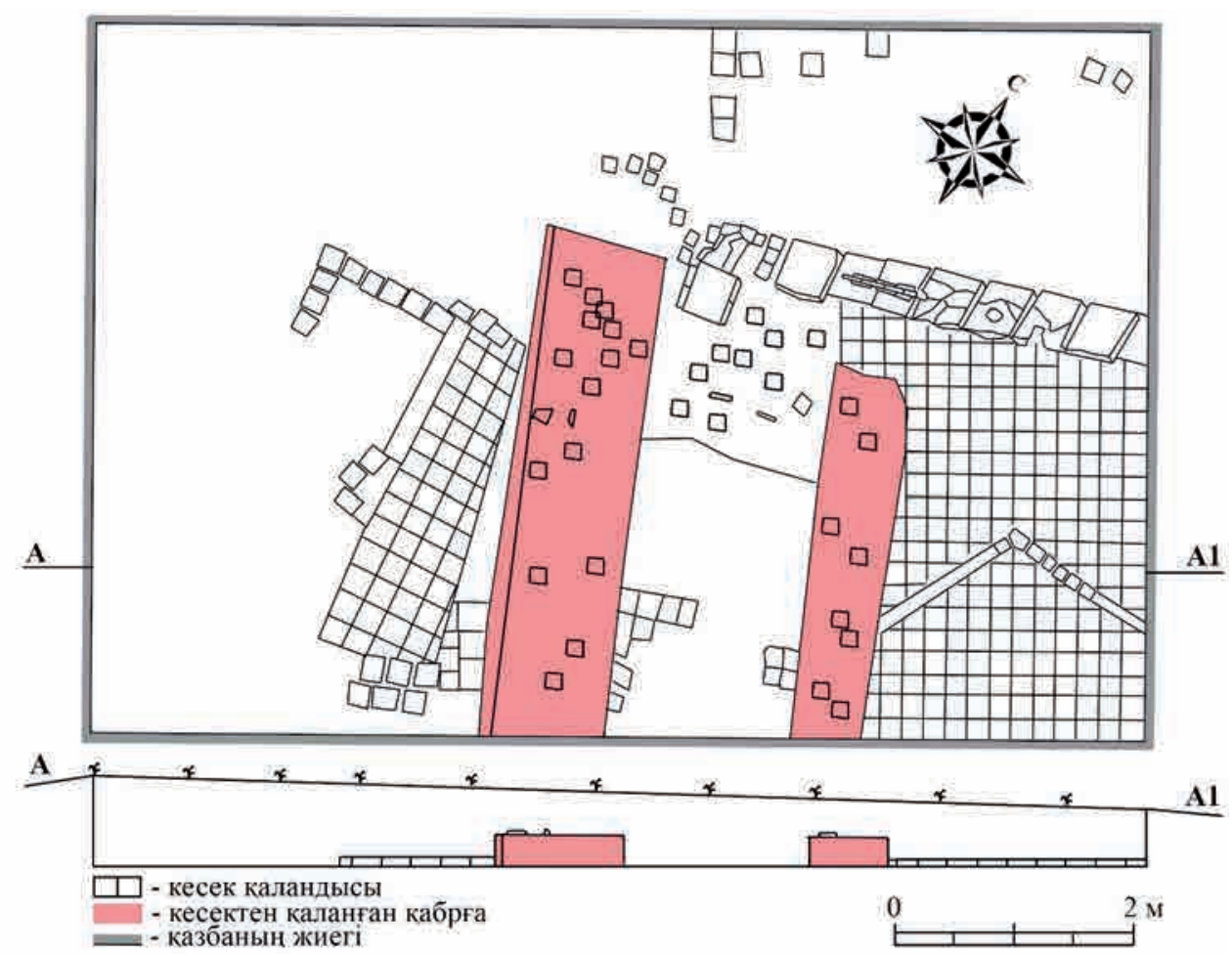

Сур. 2. Қазба I. Қазбаның, жобасы

Fig. 2. Excavation 1. Plan of the excavation 
Қабырға қашан құлағанын анықтау мүмкін емес. Өйткені құландының жоғарғы бет жағы мен қабырғалардың кірпіштерін жергілікті халық бірнеше дүркін бұзып алған. Ол баста қала тіршілігін тоқтатқаннан кейін көп ұзамай бұзылған кесененің қыштарын соңғы рет кеңес дәуірінде (19601970 жж.) колхоздарды біріктіріп, совхоз құру науқанына байланысты салынған кеңсе, мектеп, клуб құрылыстарына пайдаланған деседі. Ауыл тұрғындары жеке үй салған кезде де көне қала ғимаратарының кірпіштерін пайдаланған. Ғимараттың негізгі қабырғалары мен оның қандай көлемде болғанын анықтау мүмкін болмады. Себебі, осы жылы салынған қазба ғимараттың алдыңғы ауласы мен оның үстіне құлаған құландыларды аршумен шектелінді. Құлаған кірпіш сынықтарынан түзілген биіктігі 1 м, кей тұста одан да биік болатын құландыларды аршу қатты қолбайлау болды. Кесененің құлаған күйі сол қалпында сақталған бөлігі 8,5×5,5 м көлемді алып жатыр. Негізгі құрылыс материалы ортағасырлық дәстүрлі $26 \times 26 \times 5 ; \quad 27 \times 27 \times 6 \quad$ см көлемдегі күйдірілген кірпіштер. Құрылыстың жоғарғы жағы мен есіктің айналасын бетіне кесіп өрнек салған тақталар құрандысы жапсырылған. Өрнектері сегізбұрыш түріндегі мұсылмандық стилдегі және қошқармүйіз иректер түріндегі қазақи өрнектердің камбинациясы. Безендіру тақталарының көлемібірдейемес, көпшілігі $57 \times 57 \times 8$; $50 \times 50 \times 8 ; 50 \times 51 \times 8$ см өлшемде. Арасында $45 \times 45 \times 8$ см көлемдегі тақталар да кездеседі. Тақталардың бетіне салынған өрнектер әр тақтаның көлемінде шектелмей көрші тақтадағы өрнектерге ұласып кетеді. Кейбір тақталардың орта тұсында түрлі көлемде салынған көзшелердің орындары қалған. Шамасы көзшелер тақталарға әк слақтарымен дәнекерленген. Олардың орнында қалған әк сылақтары сақталған. Ал
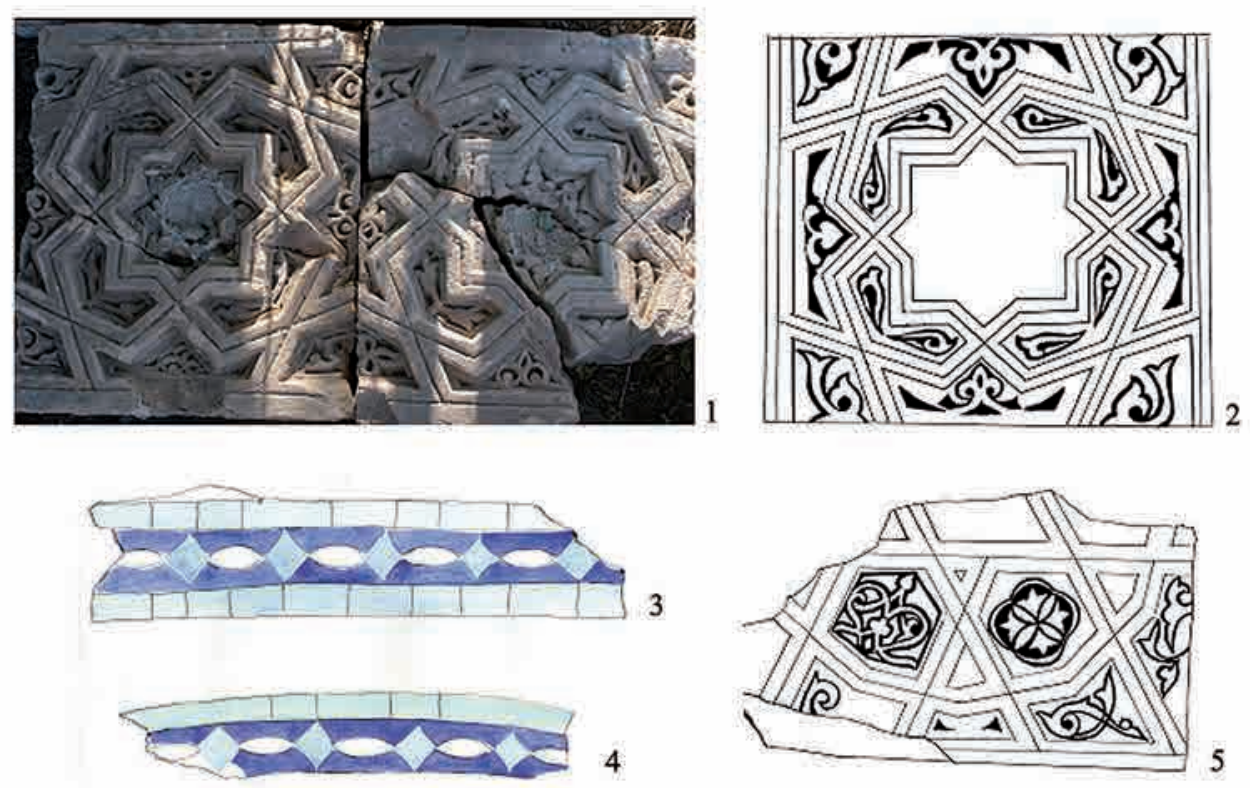

Сур. 3. Қазба 1. Кесененің қ̧ас бетін безендірген өрнектер мен мозайкалар

Fig. 3. Excavation 1. Ornament and mosaics decorated portal part of the Mausoleum 
тақталардың шеттері мен есіктің арқаларын безендірген мозайкаларды құрастыруда көк, ақ, сары, жасыл, қалампыр түстес бояулар пайдаланыпты. Төртбұрыш, домалақ, сопақша, ромба тәріздес, гүл тәріздес келген өрнектер әк сылағының бетіне құрастырылған. Арасында араб жазулары стиліндегі өрнектер де жиі кездеседі. Тұтас композициялық көріністі байқау мүмкін болмады. Өйткені, әк сылақтар ұзақ уақыт бойы әсер еткен ылғал және ыстық ауа мен үстінен әсер еткен қатты қысымның салдарынан күлдіреп кеткен. Бет жағын безендіруде мозайкадан басқа әртүрлі өлшемдегі және әртүрлі формадағы тақталар да қолданылған (сур. 3). Ғимаратың ішкі қабырғалары мен арканың беттері әк сылағының бетіне орналастырылған түрлі-түсті және түрлі пішінді жапсырмалармен қапталған. Құрылысқа арнайы өлшемде және қажетті пішінде әдейілеп жасалған кірпіштер де пайдаланылған. Олардың арасында бетіне кесіп салынған геометриялық нақыштары бар кірпіштер де кездеседі.

Қазба 2 қала шахристанының шығыс бөлігінде, қазіргі ауыл тұрғындарының қорымы орналасқан жерден 0,6 км шығыста жатқан төбелерінің біріне салынды. Төбенің оңтүстік-шығыс бөлігіне солтүстіктен оңтүстікке қарай бағыттала салынған қазбаның бастапқы көлемі $12 \times 10$ м. Қазба барысында ашыла бастаған құрылысты толық ашу мақсатында қазба 2 батыс жағынан 14×12 м қазба қосылып, қазбаның көлемі 26×22 м дейін үлкейтіліп, ол 1-1,2 м тереңдікке дейін қазылды.

Қазба барысында сегіз бұрышты құрылыс нысаны толығымен ашылды (сур. 4). Ашылған нысанының сыртқы құрылысы әртүрлі ұзындықтағы сегіз қабырға мен төрт мұнарадан тұрады. Төменгі жағы $27 \times 27 \times 6 ; 26 \times 26 \times 5$ см көлемдегі күйдірілген кірпіштен қаланған сыртқы қабырғалардың ені 1 м, сақталған биіктіктері 10-60 см. Шығыс қабырғаның ұзындығы 6 м, сақталған биіктігі 20-60 см. Қабырғаның іргетасы өзге қабырғалармен салыстырғанда біршама жақсы сақталған. Оңтүстікшығыс қабырғаның ұзындығы 10,8 м сақталғын биіктігі 5-30 см. Қабырғаның орталық бөлігінде ең төменгі бір қатар кесек қаландысы ғана сақталған. Осы қабырғаның сыртына қарай құлаған күйдірілмеген кесектен өрілген қабырғаның $4 \times 1 \times 1$ м көлемдегі құландысы жатыр. Оңтүстік қабырғаның ұзындығы 9,5 м, сақталған биіктігі 10-30 см, қабырғаның ізі толығымен көрініп тұр, батыс шетінде жеті мен төрт қатарға дейін кірпіш қаландысы сақталған. Оңтүстік-батыс қабырғаның ұзындығы 13 м, сақталған биіктігі 1030 см, қабырғаның ізі толығымен көрініп тұр, ортасында екі қатар, батыс бұрышында жеті қатар кірпішке дейін сақталған. Батыс қабырғаның ұзындығы 4,6 м, қабырғаның ізі толығымен көрініп жатыр, ортасында екі қатар, екі шетінде жеті қатарға дейін кірпіш қаландысы сақталған. Батыс, солтүстік-батыс қабырғаның ұзындығы 11,9 м, қабырғаның оңтүстік шетінде 2 м ұзындықта алты қатар кірпіш қаландысы ғана сақталған, қалған бөлігі толығымен бұзылып кеткен. Солтүстік қабырғаның жалпы ұзындығы 14,6 м, қабырғаның қақ оратсында 2,6 м келетін қақпасы бар. Қақпадан шығысқа қарай жатқан қабырғағаның төмегі бөлігінде 4-8 қатарға дейін қаланған қалдығы сақталған. Қабырғаның қалған бөлігінің кей жерлерінде бір қатар кірпіш қаландысы ғана қалған. 

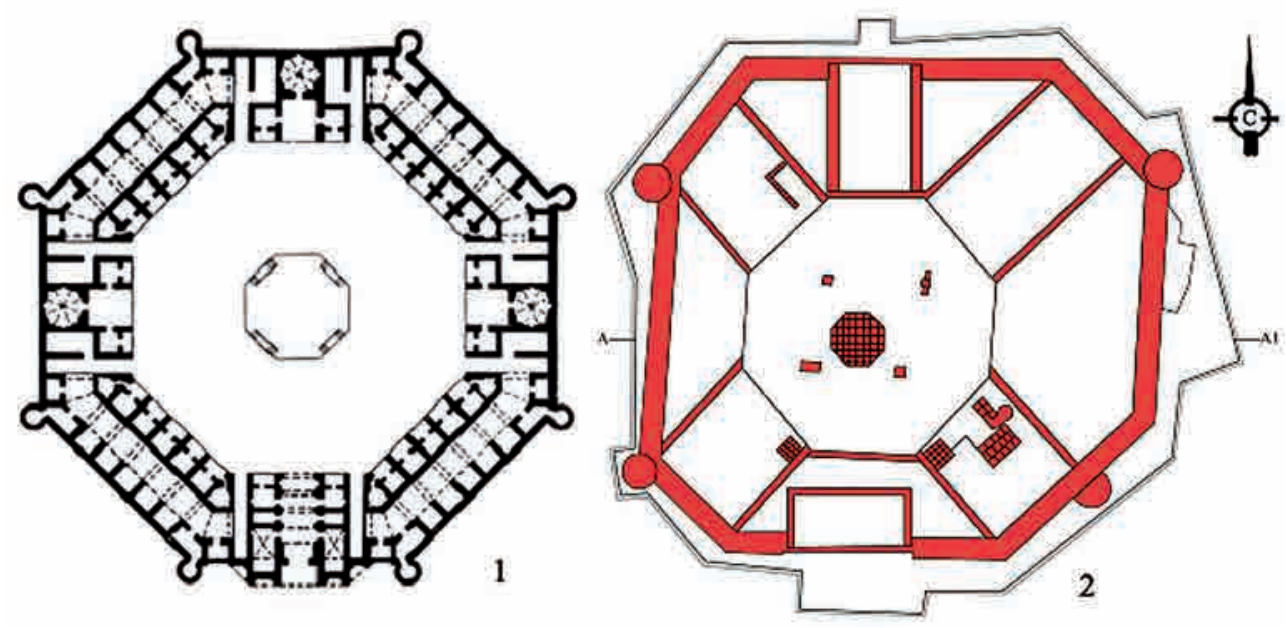

Сур. 4. Қазба 2. Қазбаның жобасы мен ован ұқ̧сас вимараттың жобасы.

1 - Иран. Амин-Абад керуен сарайьь; 2 - Қышқала, қазба 2. Ғимараттың жобасы

Fig. 4. Excavation 2. Plan of the excavation and its analogy.

1 - Iran, Amin-Abad caravanserai; 2 - Kyshkala, excavation 2. Plan

Құрылыстың сыртқы барлық қабырғаларының ені 1 м болып келеді және олардың ішкі-сыртқы жиектері күйдірілген бүтін (көлемі 27×27×5) кесектерден өріліп, ортасы кесек сынықтарымен, қою лай араластыра отырып толырылған.

Жоғарда аталғандай құрылыстың төрт бұрышында тұрғызылған дөңгелек мұнаралары бар. Құрылыстың шығыс мұнарасы шығыс және солтүстік-шығыс қабырғаларының түйіскен жерінде орналасқан, диаметрі 1,9 м, биіктігі 10-20 см. Мұнараның ең төменгі 2-3 қатар кесек қаландысы ғана сақталған. Оңтүстік мұнара оңтүстік қабырғаның бойында, шығыс бұрышынан 3,3 м аралықта орналасқан, диаметрі 1,7 м, биіктігі 40 см. Мұнараның ең төменгі алты қатар кесек қаландысы сақталған. Кесектерінің орналасу жағдайына қарағанда сыртына қарай сырғи құлағандығы байқалады. Батыс және оңтүстік-батыс қабырғаларының түйіскен жерінде орналасқан, диаметрі 1,6 м, биіктігі 20 см, мұнараның ең төменгі 2-3 қатар кесек қаландысы сақталған. Солтүстік мұнара солтүстік-батыс және солтүстік қабырғаларының түйіскен жерінде орналасқан, диаметрі 1,8 м, биіктігі 30 см. Мұнараның ең төменгі төрт қатар қаландысы сақталған.

Барлық мұнаралардың сырқы жиектері арнайы дайындалған көлемі $20 \times 20 \times 10$ см келетін, жартылай иілген күйдірілген кірпіштермен өріліп, ортасы кесек сынықтармен толтырылған. Арнайы дайындалған кесектер үшбұрышты қалыпта және бір қырын доғалдау қылып шеңбер тәрізді құрылысты өруге ыңғайлы етіп құйылған.

Ашылған нысанның қабырғаларына ішкі жағынан жапсарлас етіп салынған бірнеше бөлменің наубайы көрінеді. Нысанның ішкі жағы толық ашылып бітпегендіктен ішкі құрылыстарының ерекшеліктері мен бөлмелер саны анықталған жоқ. Қазіргі жағдайда құрлыстың ашылған бөліктерінен шамамен 10 
бөлменің орны байқалады. Кұрлыс нысанының тең ортасында аумағы $12 \times 12$ м келетін сегіз қырлы ашық алаң және осы алаңның құрлысына сәйкес келетін аумағы 2,5×2,5 м күйдірілген кірпіш төселген сегіз қырлы еденің орны сақталған.

Қабырғалары тең есес сегіз бұрышты төрт мұнаралы бұл құрылыстың қандай ғимараттың орны болғаны әзірге белгісіз. Қазбадан қыш ыдыстардың сынықтары өте сирек кездескеніне қарағанда бұл ғимарат әсте тұрғын үй қалдығы емес. Ша- масы мұсылман үлгісіндегі қандайда бір діни кешеннің, немесе қоғамдық құрылыстың орны болуы мүмкін. Бұл қазба толық аяқталмаған. Сондықтан алдын ала болжам жасау жансақ болар еді. Дегенмен, біз қазған ғимараттың жобасы Ирандағы Амин-Абад керуен-сарайына (XVI-XVIII ғғ.) ұқсас. Бірақ, оның көлемі үлкен және бұрыштары тең, мұнаралары да көп. Барлық бұрыштарында мұнаралары бар [Всеобщая история искусств, 1961, c. 95].

\section{ӘДЕБИЕТ}

$450 \mathrm{c}$

1. Археологическая карта Казахстана. Алма-Ата: изд-во АН КазССР, 1960.

2. Дербісалиев Ә. Қазақ даласының жұлдыздары (тарихи-филологиялық зертеу). Алматы: «Рауан», 1995. 141 б.

3. Байпаков К.M. Огузы, туркмены и селджуки в городах Жетысу и Южного Казахстана // Известия НАН РК. Сер. обществ. наук. 2007. № 1 (253). С. 35-61.

4. Бартольд В.В. Сочинения. Т. 1. Туркестан в эпоху монгольского нашествия. М.: Наука, 1963, 763 с.

5. Бартольд В.В. Сочинения. Т. 3. К истории орошения Туркестана. М.: Наука, $1965,713 \mathrm{c}$.

6. Всеобщая история искусств.Т. II, кн. 2. Искусство средних веков. М.: Искусство, 1961. 1028 с.

7. Жолдасбайұлы C. Жетісу тарихы (XVI-XVIII ғғ.). Тарихи және полеоэтнологиялық зерттеу. Алматы: Қазақ университеті, 1996. 300 б.

8. Извлечения из книги Киракос Гандзакеци: История Армении // Извлечения из письменных источников о средневековых городах Сауран и Сыганак / Автор предисл. и сост. М. Елеуов. Туркестан: МКТУ им. Ходжа Ахмета Ясави, 2005. 96 с. T. I. $416 \mathrm{c}$.

9. История Казахстана в персидских источниках. Алматы: Дайк-Пресс, 2005.

10. Каллаур B.А. Древние города Сыганак (Сунак), Ашнас или Эшнас (Асанас) и другие в Перовском уезде, разрушенные Чингис ханом в 1219 году // Протоколы заседаний и сообщений членов Туркестанского кружка любителей археологии. Историко-культурные памятники Казахстана. Авторы предисл. и сост. Елеуов М., Бахтыбаев М.М. Туркестан: “Туран”, 2011а. 447 с. илл.

11. Каллаур В.А. Древние города, крепости и курганы на реке Сыр-Дарье, в восточной части Перовского уезда // Протоколы заседаний и сообщений членов Туркестанского кружка любителей археологии. Историко-культурные памятники Казахстана. Авторы предисл. и сост. Елеуов М., Бахтыбаев М.М. Туркестан: “Туран”, 2011б. 447 с. илл. 3686 .

12. Қоңыыратбаев Ә. Қазақ эпосы және Туркология. Алматы: Ғылым, 1987.

13. Қоңыратбаев Ә.Қ. Жент және Баршынкент // Қоңыратбаев Ә. Көп томдық шығармалар жинағы. Алматы: Мер Сал Баспа үйі, 2004. Т. 2. Түріктану және шығыстану мәселелері. 518 б.

14. Марвұлан А.X. Из истории городов и строительного искусства древнего Казахстана. Алма-Ата: Наука, 1950. 123 с.

15. Мәмиев T. Кейінгі орта ғасырлардағы Арал өңірінің қалалары (XIIIXVIII ғғ.): тарих ғыл. канд. ... дис. Алматы, 1999. 151 б.

16. Мәмиев T. Қызылорда облысының археологиялық ескерткіштері. Алматы: «Рауан», 2000. 48 б. 
17. Путешествие в Восточные страны Плано Карпини и Гильома де Рубрука. Алматы: Ғылым, 1993. 248 с.

18. Толстов С.П. По следам древнехорезмиской экспедиции. М. - Л.: издат-во. AH CCCP 1948. 323 c.

\section{Авторлар туралы мәліметтер:}

Талеев Дөкей Абдикеримович - тарих ғылымдарының кандидаты, жетекші ғылыми қызметкер, Ә.Х. Марғұлан атындағы Археология институты (Алматы қ., Қазақстан); doc19_59@mail.ru

Елеуов Мадияр - тарих ғылымдарының докторы, профессор, әл-Фараби атындағы Қазақ Ұлттық университеті (Алматы қ., Қазақстан); madiareleuov@mail.ru

Есенов Сырым - докторант, аға ғылыми қызметкері, ҚР Ұлттық музейі (Астана қ., Қазақстан); syrym.e@mail.ru

\section{ЗАГАДОЧНАЯ СУДЬБА ГОРОДА КЫШКАЛА}

\section{Д.А. Талеев, М. Елеуов, С. Есенов}

В статье изложены результаты археологических раскопок 2018 г., проведенных на городище Кышкала. Памятник расположен близ с. Когалыкол, в 30 км к югу от г. Кызылорды. В работе приводится краткий обзор по истории археологического исследования памятника, рассмотрен вопрос о его локализации известной по письменным источникам. В определении исторического названия городища были проанализированы разные взгляды специалистов. Кроме того, опираясь на мнение многих исследователей, отождествлявших город Кышкала с Баршынкентом, расположенным на берегу древнего русла Сырдарьи - Баршындарие. Собраны также письменные сведения о городе Баршынкент.

Ключевые слова: археология, Кызылорда, Колтоган, Кышкала, Қыштобе, исследование, источники, локализация, раскопки, разведка, топография

\section{MYSTERIOUS HISTORY OF KYSHKALA}

\section{D.A. Taleev, M. Eleuov, S. Esenov}

The article presents the results of archaeological excavations in 2018, carried out at the ancient Kaskala. The monument is located near the village of Kogalykol, $30 \mathrm{~km}$ South of Kyzylorda. The paper provides a brief overview of the history of archaeological research of the monument, the question of its localization known from written sources. In determining the historical name of the settlement were analyzed different views of experts. In addition, based on the opinion of many researchers mapped the city Kaskala with Barshynkent, located on the Bank of the ancient bed of the Syr Darya - Barshyndariya. Also collected written information about the city Barshynkent.

Keywords: archaeology, Kyzylorda, Koltogan, Kyshkala, Kyshtobe, research, sources, localization, excavation, exploration, topography

\section{REFERENCES}

1. Arheologicheskaya karta Kazahstana (Archaeological map of Kazakhstan). 1960. Alma-Ata: KazSSR Academy of Sciences Publ. (in Russian).

2. Derbisaliev, A. 1995. Kazak dalasynyn juldyzdary (tarihi-filologiyalyk zerteu). Almaty: "Rauan" Publ. (in Kazakh).

3. Baipakov, K. M. 2007. In Izvestiya NAN RK. Ser. obshchestv. nauk (News of the National Academy of Sciences of Kazakhstan. Ser. societies. sciences), 1 (253), 35-61 (in Russian). Russian).

4. Bartol'd, V. V. 1963. Sochineniya (Writings), 1. Moscow: "Nauka" Publ. (in Russian).

5. Bartol'd, V. V. 1965. Sochineniya (Writings), 3. Moscow: "Nauka" Publ. (in 
6. Vseobshchaya istoriya iskusstv (The general history of art), II, kn. 2. 1961. Moscow: "Iskusstvo" Publ. (in Russian).

7. Joldasbayuly S. 1996. Jetisu tarihy (XVI-XVIII.). Tarihi jane poleoehtnologiyalyk zertteu. Almaty: "Qazaq University" Publ (in Kazakh).

8. In Izvlecheniya iz pis'mennyh istochnikov o srednevekovyh gorodah Sauran $i$ Syganak. (Extracts from written sources about the medieval cities of Sauran and Syganak). 2005. Comp. M. Eleuov. Turkestan: International Kazakh-Turkey University named Hoja Ahmet Yasavi (in Russian).

9. Istoriya Kazahstana v persidskih istochnikah (History of Kazakhstan in Persian sources), I. 2005. Almaty: "Daik-Press" Publ. (in Russian).

10. Kallaur, V. A. 2011a. In Protokoly zasedanij $i$ soobshchenij chlenov Turkestanskogo kruzhka lyubitelej arheologii. Istoriko-kul'turnye pamyatniki Kazahstana (Protocols of meetings and reports of members of the Turkestan circle of archaeology lovers. Historical and cultural monuments of Kazakhstan). Comp. Eleuov, M., Bahtybayev, M. M. Turkestan: "Turan” Publ. (in Russian).

11. Kallaur, V. A. 2011b. In Protokoly zasedanij $i$ soobshchenij chlenov Turkestanskogo kruzhka lyubitelej arheologii. Istoriko-kul'turnye pamyatniki Kazahstana (Protocols of meetings and reports of members of the Turkestan circle of archaeology lovers. Historical and cultural monuments of Kazakhstan). Comp. Eleuov, M., Bahtybayev, M. M. Turkestan: "Turan" Publ. (in Russian).

12. Konyratbayev, A. 1987. Kazakh eposy jane Turkologiya (Kazakh epos and turkology). Almaty: "Gylym" Publ. (in Kazakh).

13. Konyratbayev, A. K. 2004. In Konyratbayev, A. K. Kop tomdyk shygarmalar jinagy (Multivolume collected works), 2. Almaty: Mer Sal Baspa Publ. (in Kazakh).

14. Margulan, A. Kh. 1950. Iz istorii gorodov i stroitel'nogo iskusstva drevnego Kazahstana (From the history of cities and the building art of ancient Kazakhstan). AlmaAta: "Nauka" Publ. (in Russian).

15. Mamiev, T. 1999. Keiingi orta gasyrlardagy Aral onirinin qalalary (XIIIXVIII cc.) (Late medieval cities of Aral (XIII-XVIII cc.)): dis. ... Cand. Histor. Sciences. Almaty (in Kazakh).

16. Mamiev, T. 2000. Kyzylorda oblysynyn arheologiyalyk eskertkishteri (Archaeological sites of Kyzylorda region). Almaty: "Rauan" Publ. (in Kazakh).

17. Puteshestvie v Vostochnye strany Plano Karpini i Gil'oma de Rubruka (Travel to the Eastern countries of Plano Carpini and Guillaume de Rubruk). 1993. Almaty: "Gylym" Publ. (in Russian).

18. Tolstov, S. P. 1948. Po sledam drevnekhorezmiskoj ehkspedicii (In the wake of the ancient expedition). Moscow-Leningrad: Academy of Sciences of the USSR (in Russian).

\section{About the Authors:}

Taleev Dokey A. Candidate of Historical Sciences, Leading Researcher, A.Kh. Margulan Archeology Institute (Almaty, Kazakhstan); doc19_59@mail.ru

Eleuov Madiyar. Doctor of Historical Sciences, Professor, Al-Farabi Kazakh National University, Almaty, Kazakhstan; madiareleuov@mail.ru

Esenov Syrym. PhD student, senior researcher, KR National Museum, Astana, Kazakhstan; syrym.e@mail.ru 